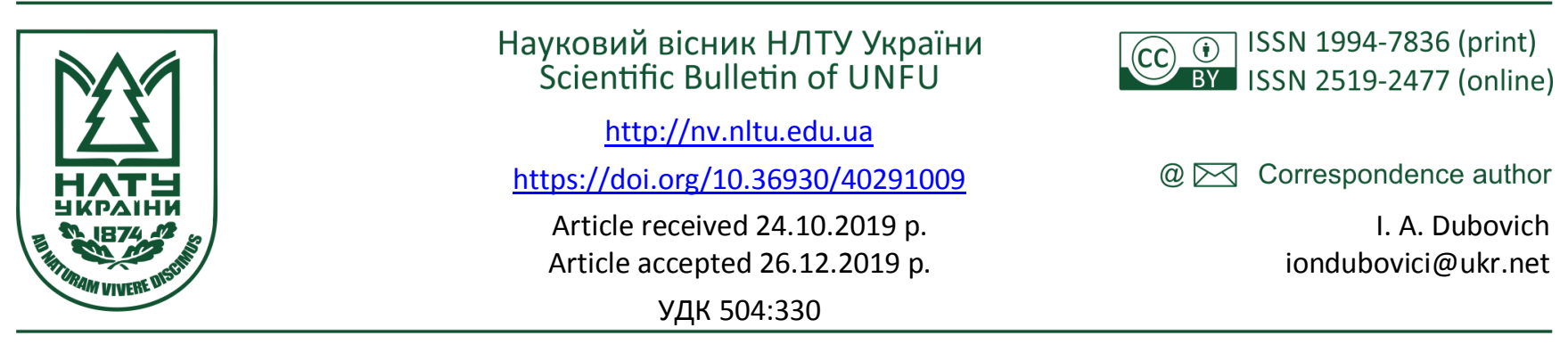

І. А. Дубовіч, Г. М. Лесюк

Начіональний лісотехнічний університет Украйни, м. Львів

\title{
КОНЦЕПТУАЛЬНІ ТЕОРЕТИЧНІ ТА ПРАКТИЧНІ ЗАСАДИ ФОРМУВАННЯ I ВПРОВАДЖЕННЯ ОСВІТИ ДЛЯ СТАЛОГО РОЗВИТКУ
}

\begin{abstract}
Звернено увагу на сутність освіти для сталого розвитку. Проаналізовано основні міжнародні ініціативи щодо формування та впровадження освіти для сталого розвитку. Окреслено відмінності між екологічною освітою і освітою для сталого розвитку. Під екологічною освітою розуміємо добре структуровану освіту, яка фокусується на відносинах між людиною та довкіллям задля його збереження, охорони та належного управління природними ресурсами. Підкреслено, що освіта для сталого розвитку - це міждисциплінарна методологія навчання, яка охоплює інтегровані соціальні, економічні та екологічні аспекти формальної, неформальної та інформальної освіти. Освіта для сталого розвитку охоплює екологічну освіту, але $є$ ширшим поняттям, що враховує соціо-культурні та соціо-політичні чинники, такі як: рівність, бідність, демократія та якість життя. Роль освіти для сталого розвитку підкреслено вкладом у розвиток знань, цінностей та навичок, необхідних для участі у прийнятті рішень для покращення якості життя на місцевому, регіональному, національному і глобальному рівнях. Визначено компетенції освіти для сталого розвитку. Проаналізовано основні завдання і підходи щодо впровадження освіти для сталого розвитку, які викладені в міжнародних документах Організації Об'єднаних Націй та Європейського Союзу. Акцентовано увагу на значеннях наукових публікацій, які стосуються практичних питань щодо формування та впровадження освіти для сталого розвитку, особливо щодо зміни навчальних планів, створення інституційних умов для просування освіти для сталого розвитку у вищих навчальних закладах, взаємодоповнювальних підходів до освіти для сталого розвитку в короткота довготерміновій перспективі. Подано хронологічний аналіз міжнародних ініціатив з освіти для сталого розвитку. Сформовано рекомендації щодо формування та впровадження освіти для сталого розвитку в Україні.

Ключові слова: освіта для сталого розвитку; екологічна освіта; сталий розвиток; фахівці для сталого розвитку; сталий спосіб життя.
\end{abstract}

Вступ. Досягнення цілей сталого розвитку потребує глибоких змін щодо поведінки та способу мислення людства. Для того, щоб створити баланс між економічними, екологічними та соціальними викликами, людство має володіти такими знаннями, навичками та цінностями, які надають можливість реалізації сталого розвитку. Освіта, зокрема вища, має вирішальне значення для досягнення сталого розвитку. Однак сучасна освіта значною мірою приділяє увагу економічному зростанню i, як результат, поширенню споживацької моделі поведінки. Сьогодні освіту для сталого розвитку (ОСР) дедалі частіше розглядають як альтернативний інструмент для організації викладання та навчання так, щоб дозволити школам, професійно-технічним навчальним закладам, університетам, громадам та приватному сектору реагувати на виклики XXI ст. Ефективна імплементація ОСР потребує належної підтримки всіх країн.

Метою роботи є розроблення теоретичних положень, методичних основ та практичних рекомендацій щодо формування та впровадження освіти для сталого розвитку.

Методами дослідження $\epsilon$ загальнонаукові методи, зокрема: аналізу та логічного узагальнення - під час добору матеріалів для дослідження, вивчення праць на- уковців, 3 метою встановлення практичних рекомендацій щодо формування та впровадження освіти для сталого розвитку та обгрунтування висновків; стратегічного аналізу - під час оцінювання стратегічних напрямів міжнародної ініціативи щодо формування та впровадження освіти для сталого розвитку; порівняльний аналіз - для дослідження відмінності між екологічною освітою і освітою для сталого розвитку; нормативний метод - для відображення освіти для сталого розвитку в законодавстві.

Ступінь розроблення проблеми та огляд літератури. Основні завдання та підходи до впровадження ОСР викладено в міжнародних документах Організації Об'єднаних Націй і Європейського Союзу, зокрема щодо реалізації завдань Десятиліття ОСР (2005-2014рр.).

В останне десятиліття значна кількість публікацій стосувалася практичним питань щодо впровадження OCP: зміни навчальних планів (Holdsworth, \& Thomas, 2015), створення інституційних умов для просування ОСР у вищій освіті (Shephard, 2010), взаємодоповнювальних підходів до ОСР у коротко- та довготерміновій перспективі (Vare, \& Scott, 2008). Окремі теоретичні та практичні аспекти запровадження ОСР в Україні викладено у працях В. Підліснюк, І. Рудика, В. Кириленка,

Інформація про авторів:

Дубовіч Іон Андрійович, канд. геогр. наук, доцент, кафедра екологічної економіки. Email: iondubovici@ukr.net

Лесюк Галина Миколаївна, аспірант, кафедра екологічної економіки. Email: lesuik.77@gmail.com

Цитування за ДСтУ: Дубовіч І. А., Лесюк Г. М. Концептуальні теоретичні та практичні засади формування і впровадження освіти для сталого розвитку. Науковий вісник НЛтУ України. 2019, т. 29, № 10. С. 49-53.

Citation APA: Dubovich, I. A., \& Lesiuk, H. M. (2019). The conceptual theoretical and practical basis of shaping and implementation of education for sustainable development. Scientific Bulletin of UNFU, 29(10), 49-53. https://doi.org/10.36930/40291009 
I. Вишенської, О. Маслюківської (Pidlisniuk, et al., 2005), Ю. Туниці (Tunytsya, et al., 2015), Л. Загвойської (Zahvoyska, 2011) та ін.

Викладення основного матеріалу. Незважаючи на те, що нині термін "освіта для сталого розвитку" (education for sustainable development) відомий академічній спільноті, в наукових джерелах трапляються такі терміни, як: "екологічна освіта" (environmental education), "екологічна освіта для сталого розвитку" (environmental education for sustainable development) "освіта для сталості" (education for sustainability) та ін. Саме тому вважаємо доцільним роз'яснити сутність освіти для сталого розвитку та окреслити їі відмінності з екологічною освітою та ін.

Освіту для сталого розвитку, на відміну від інших освітніх новацій, не запропонувала освітня спільнота. Витоки ОСР беруть свій початок з Конференції ООН з навколишнього середовища (Ріо-де-Жанейро, 1992 р.). Зокрема у Порядку денному на XXI ст. (розділ 36) "Просування освіти, публічної обізнаності та навчання" трьома ключовими напрямами визнано: вдосконалення базової освіти, переорієнтація існуючої освіти на сталий розвиток та розвиток суспільної обізнаності, розуміння та навчання для досягнення сталого розвитку (OON, 1992, р. 467). У наступні три десятиліття відбулось декілька ключових міжнародних ініціатив, які сприяли просуванню та впровадженню концепції освіти для сталого розвитку (табл. 1).

Зокрема, у 2002 р. Організація Об'єднаних Націй оголосила 2005-2014 pp. Десятиліттям ОСР і одночасно окреслила відмінності між екологічною освітою і освітою для сталого розвитку (OSR, 2019).

Екологічна освіта - добре структурована освіта, яка фокусується на відносинах між людиною та довкіллям задля його збереження, охорони та належного управління природними ресурсами. Освіта для сталого розвитку охоплює екологічну освіту, але $є$ ширшим поняттям, що враховує соціо-культурні та соціо-політичні чинники, такі як: рівність, бідність, демократія та якість життя.

ОСР - це міждисциплінарна методологія навчання, яка охоплює інтегровані соціальні, економічні та еколо- гічні аспекти формальної та неформальної навчальних програм (Education, 2019).

Основна сутність ОСР полягає в тому, що вона:

- базується на принципах та цінностях, які лежать в основі сталого розвитку;

- займається одночасно питаннями довкілля, суспільства та економіки;

- сприяє безперервному навчанню;

- базується на місцевих потребах, сприйняттях та умовах, але визнає, що задоволення місцевих потреб має глобальні наслідки;

- включає формальну, неформальну та інформальну (навчальні заходи, що відбуваються в сім'ї, на робочому місці, у місцевій громаді, у повсякденному житті, на самостійній основі (Educational, 2012, p.14) освіту;

- робить внесок у формування громадянського суспільства;

- $\epsilon$ міждисциплінарною - всі дисципліни можуть сприяти досягненню сталого розвитку;

- використовує різноманітні педагогічні методи, що сприяють участі в навчанні та розвитку критичного мислення (Report, 2012, p. 11).

ОСР охоплює чотири складові:

I. Зміст навчання: інтеграція питань охорони довкілля (зміна клімату, біорізноманіття, зменшення ризику стихійних лих, стале споживання та виробництво) у навчальні програми.

II. Педагогіка та навчальне середовище: організація викладання та навчання так, що створюється можливість для інтерактивного дослідницького, орієнтованого на результат навчання.

III. Соціальні перетворення: сприяння переходу до "зеленої" економіки, формування навичок для "зелених робочих місць", мотивація бути екологічно дружніми, "глобальними громадянами", які беруть активну участь у створенні більш справедливого, толерантного, безпечного та сталого розвитку.

IV. Результати навчання: здобуття компетенцій, що сприяють сталому способу життя, та відповідальності за теперішнє та майбутнє покоління (Development, 2019, p. 7; Scientific, 2019). Сьогодні науковці запропонували декілька класифікацій компетенцій, необхідних для перетворення способу життя індивідів для досягнення сталого розвитку (табл. 2).

Табл. 1. Хронологічний аналіз міжнародних ініціатив з ОСР*

\begin{tabular}{|c|l|}
\hline Рік & \multicolumn{1}{|c|}{ Подія } \\
\hline 1992 & $\begin{array}{l}\text { Конференції ООН з навколишнього середовища, Порядок денний на ХХІ ст., розділ } 36 \text { "Просування освіти, пуб- } \\
\text { лічної обізнаності та навчання". }\end{array}$ \\
\hline 2000 & $\begin{array}{l}\text { Світовий освітній форум у Дакарі, зобов'язання просувати "освіту для всіх" на основі сталої та добре структурова- } \\
\text { ноі співпраці, пов'язаної з стратегіями розвитку та боротьби з бідністю. }\end{array}$ \\
\hline 2000 & $\begin{array}{l}\text { Декларація тисячоліття ООН: мета 2 - забезпечити загальну початкову освіту; мета 7 - забезпечити екологічну } \\
\text { стійкість. }\end{array}$ \\
\hline 2002 & Світовий саміт у Йоганнесбурзі, рекомендація Асамблеї ООН прийняти резолюцію ОСР. \\
\hline 2005 & Стратегія ОСР Європейської економічної комісії ООН та Оголошення Десятиліття ОСР (ООН). \\
\hline 2009 & $\begin{array}{l}\text { Перший етап Десятиліття ОСР (ООН) сфокусовано на: визначенні та просуванні ОСР; встановленні партнерства; } \\
\text { визначенні процедур моніторингу та оцінки виконання. }\end{array}$ \\
\hline $2009-2014$ & $\begin{array}{l}\text { Другий етап Десятиліття ОСР (ООН) сфокусовано на: якості освіти; викладанні та змісті навчання; роботі за трьо- } \\
\text { ма основними проблемними питаннями сталого розвитку (зміни клімату, біорізноманіття та зменшення ризику ви- } \\
\text { никнення катастроф). }\end{array}$ \\
\hline 2012 & $\begin{array}{l}\text { Конференція ООН з сталого розвитку (Ріо+20), "Майбутнє якого ми хочемо": освіта є важливою для "зеленої" еко- } \\
\text { номіки, зайнятості населення та соціального захисту. }\end{array}$ \\
\hline 2014 & $\begin{array}{l}\text { Світова конференція з ОСР 4 цілі: святкування десятиліття ОСР; переорієнтація освіти для кращого майбутнього } \\
\text { всіх; пришвидшення виконання; визначення ОСР після 2014 р. Конференція запустила Глобальну програму дій } \\
\text { ОСР. }\end{array}$ \\
\hline 2015 & $\begin{array}{l}\text { Агенда для сталого розвитку до 2030 р., мета 4 - "Якість освіти" (4.7 - забезпечити тих, хто навчається, знаннями } \\
\text { та навичками, необхідними для просування сталого розвитку). }\end{array}$ \\
\hline
\end{tabular}

Примітка: *Розробили автори на основі (Development, 2017, p. 7; Decade, 2014, p. 17; Education, 2000, p. 8). 
Табл. 2. Компетенції освіти для сталого розвитку (Development, 2018, pp. 41-42)

\begin{tabular}{|c|c|}
\hline $\begin{array}{l}\text { Науковці / організації, } \\
\text { які запропонували } \\
\text { класифікацію }\end{array}$ & Компетенції \\
\hline $\begin{array}{c}\text { ОБСС проект } \\
\text { "Визначення та вибір } \\
\text { компетенцій" }\end{array}$ & $\begin{array}{l}\text { Використання інструментів в інтерактивному режимі (використання мови, символів і текстів в інте- } \\
\text { рактивному режимі, вміння застосовували знання та інформацію в інтерактивному режимі, а також } \\
\text { можливість використання технологій інтерактивно); взаємодія в гетерогенних групах (здатність до } \\
\text { співпраці, а також здатність керувати і вирішувати конфлікти); здатність діяти самостійно (здатність } \\
\text { діяти всередині групи; вміння формувати і виконувати плани та особисті проекти; здатність захища- } \\
\text { ти і заявляти про особисті права, інтереси, потреби). }\end{array}$ \\
\hline Haan, 2010 & $\begin{array}{l}\text { Думати і діяти, орієнтуючись на майбутні цілі; отримувати міждисциплінарні знання; опрацьовува- } \\
\text { ти складну інформацію; співпрацювати в процесі прийняття рішень; самостійно приймати рішення; } \\
\text { брати участь у колективному процесі прийняття рішень; мотивувати себе та інших; роздумувати про } \\
\text { свої принципи та принципи інших; посилатися на ідею справедливості у процесі прийняття рішень } \\
\text { та планування дій; планувати і } \\
\text { діяти автономно; здатність співчувати особам, котрі знаходяться у несприятливих умовах. }\end{array}$ \\
\hline Delphi study & $\begin{array}{l}\text { Системне мислення та опрацювання складних завдань, превентивне мислення, критичне мислення, } \\
\text { здатність діяти справедливо та екологічно дружно, співпраця в гетерогенних групах, участь, емпатія } \\
\text { та зміна перспектив, міждисциплінарна робота, спілкування та використання засобів масової інфор- } \\
\text { мації, планування та реалізація інноваційних проектів, оцінка та невизначеність, терпимість до роз- } \\
\text { чарування. }\end{array}$ \\
\hline $\begin{array}{l}\text { Wiek, Withycombe and } \\
\text { Redman, } 2011 \text {, Wiek et al., } \\
2016\end{array}$ & $\begin{array}{l}\text { Системне мислення, превентивне мислення, нормативна } \\
\text { компетенція, стратегічна компетенція, міжособистісна компетенція та інтегрована компетенція вирі- } \\
\text { шення проблем. }\end{array}$ \\
\hline Glasser and Hirsh 2016 & $\begin{array}{l}\text { Прихильність до всього живого, знання про стан планети, мудрі рішення, моделювання поведінки, } \\
\text { що сприяє сталому розвитку, та трансформаційні соціальні зміни. }\end{array}$ \\
\hline
\end{tabular}

ОСР дає змогу повністю розвивати знання, цінності та навички, необхідні для участі у прийнятті рішень для покращення якості життя на всіх рівнях (місцевому, регіональному, національному і глобальному). Питання, яке сьогодні постає стоїть перед освітнім співтовариством, - як реалізувати освіту для сталого розвитку на практиці. Це має бути ефективний інструмент, спрямований на трансформацію суспільства на шляху до сталого розвитку (Bhawani Venkataraman, 2009, p. 8).

Теоретико-методичним положенням щодо ефективної імплементації ОСР у практику є підтримка цієї концепції на національному та міжнародному рівнях. У 2005 р. на нараді високого рівня представники міністерств охорони довкілля та освіти прийняли Стратегію ОСР Європейської економічної комісії ООН (Bonelli, 2018).

Метою Стратегії є сприяння інтеграції ОСР у всі освітні рівні, зокрема професійну освіту та "освіту для дорослих". Цілями Стратегії є:

- забезпечення ОСР політичною, регуляторною та оперативною підтримкою;

- просування сталого розвитку через формальну, неформальну та інформальну освіту;

- забезпечення освітян еколого-економічними компетентностями, що дають змогу включити сталий розвиток у їхне викладання;

- забезпечення освітнього процесу належними інструментами та матеріалами для ОСР;

- просування досліджень з ОСР;

- посилення кооперації з ОСР у всіх регіонах Європейської економічної комісії ООН (UNECE, 2016, p.1).

Підсумковий звіт виконання Стратегії ОСР формується на основі національних звітів з імплементації ОСР, що включають аналіз виконання 18 індикаторів. 38 держав з 56 держав-членів Свропейської економічної комісії ООН подали національні звіти з імплементації ОСР у третій період звітування (2011-2015рр.). У перший (2005-2007 рр.) та другий (2008-2010 рр.) періоди звітування 3 впровадження ОСР 35 та 36 держав подали звіти відповідно (UNECE, 2016, р. 4-5).
Основними висновками виконання Стратегії ОСР Європейської економічної комісії ООН є:

- ОСР включена в національну освітню політику в понад 90 \% держав-членів Свропейської економічної комісії ООН, що подали звіти;

- 89 \% держав-членів Свропейської економічної комісії ООН, що подали звіти, вважають, що ОСР $є$ частиною їхньої політики сталого розвитку;

- 84 \% держав-членів, що подали-звіти, вважають, що ОСР включена до навчальних планів початкового та середнього освітніх рівнів;

- 90 \% держав-членів повідомляють, що методи та інструменти ОСР використовуються у формальній та неформальній освіті, $70 \%$ - зазначають включення питань сталого розвитку в навчання на робочому місці (UNECE, 2016, p 8-10).

3 аналізу національних стратегій освіти для сталого розвитку видно, що національні стратегії освіти для сталого розвитку охоплюють:

- Цілі та основні сфери діяльності (навчальні плани дошкільної, початкової та середньої освіти, професійна освіта, додаткова освіта/тренінг, вища освіта та дослідження, сприяння участі молоді).

- Зацікавлені сторони та комунікацію.

- План реалізації (відповідальні сторони та бюджет). Відповідальними сторонами зазвичай $є$ державні органи управління, що реалізують освітню політику, освітні заклади. Фінансуються заходи 3 впровадження освіти для сталого розвитку 3 державних бюджетів, структурних фондів ЄC (Bonelli, 2018).

- Моніторинг та оцінка стратегії. Оцінка виконання стратегії зазвичай відбувається на основі індикаторів - кількості освітніх програм, що включають питання, дотичні до сталого розвитку; кількості профінансованих проектів щодо сталого розвитку; кількості експертів, котрі володіють методиками ОСР та ін. (Sustainable, 2011).

В Україні освіту для сталого розвитку підтримують державні органи управління та міжнародні організації, зокрема: Міністерство освіти і науки України, Міністерство екології і природних ресурсів України, Інститут Інноваційних технологій, Інститут освіти Національної академії педагогічних наук України, Глобальний еколо- 
гічний фонд, Шведське агентство з питань міжнародної співпраці та розвитку, Британська Рада в Україні, Організація з безпеки і співробітництва в Європі та ін. (Isaenko, 2017, p. 112).
Зауважимо, що сьогодні, національної стратегії ОСР в Україні немає, натомість ОСР відображена в законодавстві (табл. 3).

Табл. 3. Освіта для сталого розвитку, відображена в законодавстві України (Natsionalnu, 2019; Vidomosti, 2011, 2017)

\begin{tabular}{|l|l|}
\hline \multicolumn{1}{|c|}{ Джерело } & \multicolumn{1}{|c|}{ Зміст } \\
\hline $\begin{array}{l}\text { Закон України "Про Основні положення (страте- } \\
\text { гію) державної екологічної політики України на } \\
\text { період до 2020 р." (2010 р.) }\end{array}$ & $\begin{array}{l}\text { Екологічна просвіта та виховання підростаючого покоління шляхом під- } \\
\text { тримки діяльності позашкільних закладів освіти, еколого-натуралістичних } \\
\text { центрів та природничих секцій центрів дітей та юнацтва (п. 4.9 Стратегії). }\end{array}$ \\
\hline $\begin{array}{l}\text { Указ Президента України "Про Національну } \\
\text { стратегію розвитку освіти в Україні на період до } \\
2021 \text { р." (2013 р.) }\end{array}$ & $\begin{array}{l}\text { Оновлення цілей і змісту освіти на основі компетентнісного підходу та осо- } \\
\text { бистісної орієнтації, урахування світового досвіду та принципів сталого } \\
\text { розвитку; потреба підготовки фахівців для сталого розвитку з новим еколо- } \\
\text { гічним мисленням (розділи 3 та 4 Указу). }\end{array}$ \\
\hline Закон України "Про освіту" (2017 р.) & $\begin{array}{l}\text { Підвищення освітнього рівня громадян задля забезпечення сталого розвит- } \\
\text { ку України та ії європейського вибору. }\end{array}$ \\
\hline
\end{tabular}

Вважаємо, що оцінювати напрацювання ОСР в Україні варто з позиції загальноінституційного підходу. Загальноінституційний підхід до ОСР потребує зміни не тільки навчальної програми та методики викладання, але i процесу управління та адміністративно-господарської роботи в закладах освіти. Загальноінституційний підхід передбачає: 1) залучення адміністрації, викладачів та осіб, котрі навчаються, до спільного розроблення місії та плану впровадження ОСР у закладі освіти; 2) технічну та фінансову підтримку діяльності, спрямованої на формування та впровадження ОСР; 3) мобілізацію співпраці закладу освіти з іншими закладами освіти для просування ОСР (Development, 2019, p. 4).

Вважаємо, що оцінювати формування та впровадження ОСР в Україні потрібно не на основі декларативного утвердження в нормативно-правовій базі України, а на основі реалізації принципу "сталості в дії". За сприяння Агенції з питань розвитку співпраці SIDA (Міністерство закордонних справ Швеції) в Україні реалізується проект "Освіта для сталого розвитку в дії"", метою якого навчити учнів шкіл умінням та навичкам, що сприяють організації власного життя, життя сім'ї, місцевої громади з урахуванням потреб сталого розвитку (Osvita, 2019). У межах проекту також реалізується програма "Стале домогосподарство", спрямована на навчання дорослих навичкам сталого способу життя (Domogospodarstvo, 2019).

У вищих закладах освіти України концепція ОСР реалізується зазвичай шляхом екологізації освітнього процесу, що передбачає включення питання охорони довкілля в навчальні плани освітньо-кваліфікаційних різних галузей знань і спеціальностей. Однак, що впровадження "сталості в дії" ("зелені кампуси", зменшення використання енергетичних ресурсів, менеджмент відходів та ін.) для закладів вищої освіти є слабкою стороною. Тобто формування та впровадження ОСР в Україні переважно відбувається через підхід "освіта про сталий розвиток" (коли особам, котрі навчаються, намагаються пояснити сутність сталого розвитку), а не через підхід "освіта для сталого розвитку" (коли результатом навчання є здатність вести сталий спосіб життя).

На нашу думку, для реалізації ОСР потрібно:

- проводити періодичний моніторинг реалізації завдань і цілей ОСР, уже окреслених у законодавстві України, що створить можливості для успішного впровадження ОСР у довготерміновій перспективі на національному рівні;

- формувати цілі та завдання ОСР, одночасно охоплюючи всі компоненти: зміст навчання, навчальне середовище, результати навчання, очікувані соціальні перетворення;
- готувати висококваліфікованих фахівців для сталого розвитку. Зазначимо, що в п. 5. Рішення колегії МОН України "Про екологізацію вищої освіти України з метою підготовки фахівців для сталого розвитку" (від 27 листопада 2015 р.) зазначено про потребу підготовки та внесення до національного Класифікатора професій ДК 003:2010 нової професії "економіст-еколог" (MON, 2019);

- надавати підтримку неформальній та інформальній освіті для збільшення кількості осіб, обізнаних з питаннями охорони довкілля, сталого розвитку та ведення сталого способу життя;

- співпрацювати із засобами масової інформації щодо підвищення інформованості громадськості про сталий розвиток;

- диверсифіковувати методи навчання для розвитку критичного мислення в осіб, котрі навчаються (дискусії, концептуальне та перцептуальне відображення, роз'яснення, сценарії, моделювання, рольові ігри, інформація та комунікаційні технології, опитування, тематичні дослідження, екскурсії та навчання на вулиці, навчальні проекти);

- залучати додаткові джерела фінансування для реалізації проектів, спрямованих на "сталість в дії";

- створювати партнерські мережі, що об'єднають освітян, громадські організації, приватний сектор, державні установи для поширення матеріалів і практик ОСР.

Висновки. Формування та впровадження ОСР потребують підтримки всіх країн та подальшого опрацювання інструментів ОСР. Розуміння, обізнаність питань сталого розвитку суспільства, участь та партнерство $€$ ефективними підходами до формування та впровадження ОСР. Передумовою успішного формування та реалізації ОСР є структуризація заходів, термінів та індикаторів стратегії. Деякі проекти ОСР за міжнародної підтримки реалізовано і в Україні. Враховуючи те, що ОСР орієнтована на інтереси теперішнього і майбутніх поколінь, потрібно інтенсифікувати зусилля з іiі формування та впровадження на всіх рівнях освіти.

\section{References}

Bhawani Venkataraman. (2009). Education for Sustainable Development, Environment. Science and Policy for Sustainable Development, 51(2), 8-10.

Bonelli, P. (2018). Strategy for ESD, the commitment of Italian Institutions. World Environmental Congress. Retrieved from: https://weecnetwork.org/strategy-esd-commitment-italian-institutions/

Decade. (2014). Shaping the Future We Want. UN Decade of Education for Sustainable Development (2005-2014): final report. United Nations Educational, Scientific and Cultural Organization, 198 p.

Development. (2017). Education for Sustainable Development Goals Learning Objectives. United Nations Educational, Scientific and Cultural Organization, $68 \mathrm{p}$. 
Development. (2018). Issues and trends in Education for Sustainable Development. United Nations Educational, Scientific and Cultural Organization, $271 \mathrm{p}$.

Development. (2019). Global Action Programme on Education for Sustainable Development as follow-up to the United Nations Decade of Education for Sustainable Development after 2014. United Nations Educational, Scientific and Cultural Organization, 7 p. Retrieved from: http://www.mext.go.jp/en/unesco/title04/detail04/sdetail04/icsFiles/afieldfile/2016/10/11/1375695 01.pdf

Domogospodarstvo. (2019). Programa "Stale domogospodarstvo". Retrieved from: http://domogospodarstvo.esd.org.ua/node/7. [In Ukrainian].

Education. (2000). The Dakar Framework for Action 7. Education for All: Meeting Our Collective Commitments. World Education Forum Drafting Committee, $78 \mathrm{p}$.

Education. (2019). Education for sustainable development. Higher Education Academy. Retrieved from: https://www.heacademy.ac.uk/knowledge-hub/education-sustainable-development-0

Educational. (2012). International Standard Classification of Education ISCED. United Nations Educational, Scientific and Cultural Organization, $88 \mathrm{p}$.

Holdsworth, S., \& Thomas, I. (2015). Framework for Introducing Education for Sustainable Development into University Curriculum. Journal of Education for Sustainable Development, 9(2), 137159.

Isaenko, V. (2017). The challenges of today in Ukraine: Education for Sustainable Development. Intercultural Communication, 1/2, 108122.

MON. (2019). Kolehiia MON rozghlianula pytannia "Pro ekolohizatsiiu vyshchoi osvity Ukrainy z metoiu pidhotovky fakhivtsiv dlia staloho rozvytku". Retrieved from: http://nltu.edu.ua/index.php? option=com_content\&view=article\&id=843:-q-q\&catid=13:2009-1210-10-49-15\&Itemid $=244$. [In Ukrainian].

Natsionalnu. (2019). Ukaz Prezydenta Ukrainy "Pro Natsionalnu stratehiiu rozvytku osvity $v$ Ukraini na period do 2021 roku" vid 25.06.2013, \#344/2013. Retrieved from: http://zakon.rada.gov.ua/laws/show/344/2013. [In Ukrainian]

OON. (1992). Povestka dnia na XXI vek. Konferentciia OON po okruzhaiushchei srede i razvitiiu, Rio-de-Zhaneiro, 505 p. Retrived from: $\quad \mathrm{http} / / / \mathrm{www} . u n . o r g / \mathrm{ru} /$ documents/decl conv/conventions/pdf/agenda21.pdf. [In Russian]

OSR. (2019). Osvita dlia staloho rozvytku (OSR): rozvytok kontseptsii v ramkakh protsesu "Dovkillia dlia Yevropy" ta osnovni dosiahnen- nia $v$ Ukraini. Retrieved from: http://ecoosvita.org.ua/storinkaknygy/osvita-dlya-stalogo-rozvytku. [In Ukrainian].

Osvita. (2019). Mizhnarodnyi osvitnii proekt dlia shkilnoi molodi ta doroslykh "Osvita dlia staloho rozvytku $v$ dii". Retrieved from: $\mathrm{http} / / /$ www.esd.org.ua/node/129. [In Ukrainian].

Pidlisniuk, V., Rudyk, I., Kyrylenko, V., Vyshenska, I., \& Masliukivska, O. (2005). Stalyi rozvytok suspilstva: rol osvity. Putivnyk. Kyiv: Publishing SPD "Kovalchuk", 88 p. [In Ukrainian].

Report. (2012). Shaping the Education of Tomorrow: Full-length Report on the UN Decade of Education for Sustainable Development. United Nations Educational, Scientific and Cultural Organization, $102 \mathrm{p}$.

Scientific. (2019). What is ESD? United Nations Educational, Scientific and Cultural Organization. Retrieved from: https://en.unesco.org/themes/education-sustainable-development/what-is-esd

Shephard, K. (2010). Higher Educations Role in Education for Sustainability. Australian Universities Review, 52(1), 13-22.

Sustainable. (2011). Action plan for education for sustainable development. Ministry of Environmental Protection of Republic of Croatia, 41 p. Retrieved from: https://www.mzoip.hr/doc/education_for_sustainable_development_action_plan.pdf

Tunytsya, Yu. Yu., Adamovsky, M. G., Borys, M. M., Kraievskyi, S. N., \& Magazynshchykova, I. P. (2015). Ekolohizatsiia osvity yak kliuchovyi faktor pidhotovky fakhivtsiv dlia staloho rozvytku. Scientific Bulletin of UNFU, 25(10), 348-356. https://doi.org/10.15421/40251053

UNECE. (2016). Ten years of the UNECE Strategy for Education for Sustainable Development: Evaluation report on the implementation of the UNECE Strategy for Education for Sustainable Development from 2005 to 2015 . United Nations, $125 \mathrm{p}$.

Vare, P., \& Scott, W. A. H. (2008). Education for Sustainable Development: two sides and an edge. London: DEA.

Vidomosti. (2011). Zakon Ukrainy "Pro Osnovni polozhennia (stratehiiu) derzhavnoi ekolohichnoi polityky Ukrainy na period do 2020 roku". Vidomosti Verkhovnoi Rady Ukrainy (VVR), № 26, p. 218. Retrieved from: http://zakon.rada.gov.ua/laws/show/2818-17. [In Ukrainian].

Vidomosti. (2017). Zakon Ukrainy "Pro osvitu". Vidomosti Verhovnoyi Rady (VVR), № 38-39. Retrieved from: http://zakon.rada.gov.ua/laws/show/2145-19. [In Ukrainian].

Zahvoyska, L. D. (2011). Osvita dlya stalogo rozvytku: napratsyuvannya ta zavdannya. Scientific Bulletin of UNFU, 21(19), 7-13. [In Ukrainian].

I. A. Dubovich, H. M. Lesiuk

Ukrainian National Forestry University, Lviv, Ukraine

\section{THE CONCEPTUAL THEORETICAL AND PRACTICAL BASIS OF SHAPING AND IMPLEMENTATION OF EDUCATION FOR SUSTAINABLE DEVELOPMENT}

Attention is paid to the essence of education for sustainable development. The main international initiatives on the shaping and implementation of education for sustainable development are analyzed. The differences between environmental education and education for sustainable development are outlined. Environmental education is defined as well-structured education, which focuses on the relationship between man and the environment in order to preserve, protect and properly manage natural resources. The education for sustainable development is interpreted an interdisciplinary teaching methodology that covers integrated social, economic and environmental aspects of formal, informal and non-formal education. Education for sustainable development embraces environmental education, but it is a broader concept that takes into account socio-cultural and socio-political factors such as equality, poverty, democracy and quality of life. The role of education for sustainable development is emphasized by the contribution to the development of knowledge, values and skills needed to participate in decision-making to improve the quality of life at the local, regional, national and global levels. The competences of education for sustainable development are defined. The main tasks and approaches to the implementation of education for sustainable development, which are outlined in the international documents of the United Nations and the European Union, are analysed. The emphasis is placed on the importance of scientific publications devoted to the practical issues of the shaping and implementation of education for sustainable development, especially regarding the change of curricula, the creation of institutional conditions for the promotion of education for sustainable development in higher education institutions, complementary approaches to the education for sustainable development in the short and long term. A chronological analysis of international initiatives for education for sustainable development is done. The recommendations for the shaping and implementation of education for sustainable development in Ukraine are presented.

Keywords: education for sustainable development; environmental education; sustainable development; specialists on sustainable development; sustainable lifestyle. 